\title{
AN UPDATED ANNOTATED CHECKLIST OF THE MOLLUSCS OF THE REPUBLIC OF MOLDOVA
}

\author{
IGOR A. BALASHOV ${ }^{1}$, MikHAIL O. SON${ }^{2}$, VIORICA COADÄ ${ }^{3}$, FRANCISCO WELTER-SCHULTES ${ }^{4}$ \\ ${ }^{1}$ Schmalhausen Institute of Zoology, National Academy of Sciences of Ukraine, B. Khmelnytsky 15, Kiev, \\ 01601, Ukraine (e-mail: igor_balashov@ukr.net) \\ ${ }^{2}$ Odessa Branch Institute of Biology of the Southern Seas, National Academy of Sciences of Ukraine, \\ Pushkinskaya 37, Odessa, 65011, Ukraine (e-mail: michail.son@gmail.com) \\ ${ }^{3}$ Tiraspol State University, Gh. Iablocikin 5, MD 2069, Chişinău, Republic of Moldova \\ (e-mail: vioricacoada@gmail.com) \\ ${ }^{4}$ Zoological Institute of Göttingen University, Berliner Strasse 28, 37073, Göttingen, Germany \\ (e-mail: fwelter@gwdg.de)
}

ABSTRACT: An updated annotated checklist of the molluscs of the Republic of Moldova is provided. It includes 155 species: 26 bivalves, 45 freshwater gastropods and 84 terrestrial gastropods. Some species such as Truncatellina claustralis, Granaria frumentum, Perpolita petronella and Tandonia kusceri are reported for the first time from Moldova by original data. A number of unclear species reports are discussed.

KEY WORDS: molluscs, Mollusca, Gastropoda, Bivalvia, checklist, Moldova

\section{INTRODUCTION}

The first annotated checklist of the molluscs of the Republic of Moldova, which included 112 species, was published recently (COADĂ \& WELTER-SCHULTES 2011), but unfortunately some literature data were overlooked and this list was incomplete. Moreover, some unpublished data from collection material became available in the last few years. This created a need to update that previous checklist. Our new checklist includes 155 species: 26 bivalves, 45 freshwater gastropods and 84 terrestrial gastropods.

Since views on taxonomy of the freshwater molluscs are quite controversial, we follow here mainly a recent guide of European non-marine molluscs (WELTER-SCHULTES 2012) to make the list better available to the European reader. A list of the freshwater molluscs of the Republic of Moldova in the classification applied by the Russian malacologists of Starobogatov's school was published recently and included 100 species (MUNJIU 2012). We did not try to make any nomenclatural revision here, but intended only to adapt this list of 100 species for the European reader. Since STAROBOGATOV and his followers frequently use specific names not in the sense of their original authors (for most complete list see: STAROBOGATOV et al. 2004), we could not just list these additional names as synonyms of recognised species. Many of these names are not synonyms in the taxonomic sense (which would require studying the type material), but only synonyms in the sense of these authors. We can only suggest from our experience which species can more likely be understood or determined under these names. Names that are marked by "auctorum non..." refer to a synonym in the sense of some authors (here mainly STAROBOGATOV and his followers) but not the author of the species name. However many of these names are nomina dubia without types and we did not study this problem in detail, so it is also possible that some of these names are actually correct synomyms in the sense of their authors. For this reason we mark such names with "auct. non [?] ...".

Species that were not given in the previous checklist (COADĂ \& WELTER-SCHULTES 2011) are highlighted in bold. We mention only those synonyms which have been in use in Moldova over the last several years. 


\section{MOLLUSCS OF MOLDOVA - CHECKLIST}

\section{Gastropoda}

Neritidae Rafinesque, 1815

Theodoxus cf. danubialis (Pfeiffer, 1828)

In past publications $T$. danubialis has been reported many times from Moldova (YAROSHENKO 1957, GONTYA 1984, 1985, MUNJIU 2009, 2012, MUNJIU \& SHUBERNETSKI 2010, COADĂ \& WELTERSCHULTES 2011, WELTER-SCHULTES 2012), but in the opinion of some authors (ANISTRATENKO et al. 1999, SON 2010) an endemic species, Theodoxus donasteri (Lindholm, 1908) lives in the northern basin of the Black Sea. According to these authors, reports of $T$. danubialis and maybe of some other species refer to this endemic. The last revision of T. danubialis provided no data about its occurrence in the Dniester and lower sections of other Ponto-Caspian rivers (BUNJE 2007). Some recent preliminary molecular data partly supported a separation of T. donasteri (see BUNJE 2005, SEREDA et al. 2007). More research is needed to clarify the taxonomic status of this species. A recent report of the marine species Theodoxus pallasi Lindholm, 1924 (see MUNJIU 2012) requires confirmation for Moldova, where no marine ecosystems exist (see discussion below). The Theodoxus species of Moldova require a revision.

Theodoxus euxinus (Clessin, 1886)

This brackish water species is present in the marine part of the Dniester Liman, but its occurrence in the Moldavian part of the Dniester River (MUNJIU \& SHUBERNETSKI 2010, MUNJIU 2012) requires confirmation. It is possible that fossil shells were involved or that this occurrence was a result of casual transfer by birds or man.

Theodoxus fluviatilis (Linnaeus, 1758)

Theodoxus transversalis (Pfeiffer, 1828)

Viviparidae Gray, 1847

Viviparus contectus (Millet, 1813)

Viviparus viviparus (Linnaeus, 1758)

Valvatidae Gray, 1840

Borysthenia naticina (Menke, 1845)

Reported from the Dniester Basin (YAROSHENKO 1957, MuNJIU 2012). Perhaps extinct in Moldova.

Valvata cristata Müller, 1774

Valvata macrostoma Mörch, 1864

Syn. V. pulchella auct. non Studer, 1789

Valvata piscinalis (Müller, 1774)

Syn. V. profunda auct. non [?] Clessin, 1887, V. ambigua auct. non [?] Westerlund, 1878

Pomatiidae Newton, 1891

Pomatias rivularis (Eichwald, 1829)
Aciculidae Gray, 1850

Platyla polita (Hartmann, 1840)

Bithyniidae Gray, 1857

Bithynia leachii (Sheppard, 1823)

Syn. B. troschelii (Paasch, 1842), B. inflata (Hansen, 1845)

Occurring in the Dniester and Prut rivers (YAROSHENKO 1957, GONTYA 1984, 1985, MUNJIU 2012).

Bithynia tentaculata (Linnaeus, 1758)

Hydrobiidae Stimpson, 1865

Lithoglyphus naticoides (Pfeiffer, 1828)

Potamopyrgus antipodarum (Gray, 1843)

Syn. P. jenkinsi (Smith, 1889)

This non-native species was recorded in the $\mathrm{Ku}$ churhan Liman (SON 2008, MUNJIU \& SHUBERNETSKI 2010, MUNJIU 2012).

Turricaspia lincta (Milaschevich, 1908)

Turricaspia triton (Eichwald, 1838)

Thiaridae Troschel, 1857

Esperiana esperi (Férussac, 1823)

Microcolpia daudebartii (Prevost, 1821)

Syn. M. acicularis (Férussac, 1823)

Physidae Fitzinger, 1833

Aplexa hypnorum (Linnaeus, 1758)

Physa acuta Draparnaud, 1805

Physa fontinalis (Linnaeus, 1758)

Syn. Physa taslei auct. non [?] Bourguignat, 1860

Occurring in the Prut River, Kuchurhan Liman and other water bodies (YAROSHENKO 1957, MUNJIU 2009, 2012).

Lymnaeidae Rafinesque, 1815

Galba truncatula (Müller, 1774)

Lymnaea stagnalis (Linnaeus, 1758)

Myxas glutinosa (Müller, 1774)

Occurs in the Dniester River (GîlCĂ et al. 2010, MUNJIU 2012).

Radix auricularia (Linnaeus, 1758)

Radix balthica (Linnaeus, 1758)

Syn. R. ovata (Draparnaud, 1805)

It occurs in the Dniester and Prut rivers, Kuchurhan Liman and other water bodies (YAROSHENKO 1957, MuNJIU 2012).

Radix labiata (Rossmässler, 1835)

Syn. R. peregra (Müller, 1774)

Stagnicola palustris (Müller, 1774)

Occurring in the Dniester Basin (YAROSHENKO 1957, GONTYA 1984, MUNJIU 2009, 2012). It was probably not determined anatomically, further investigation of Moldavian Stagnicola is needed. 
Acroloxidae Thiele, 1931

Acroloxus lacustris (Linnaeus, 1758)

Planorbidae Rafinesque, 1815

Ancylus fluviatilis Müller, 1774

Anisus septemgyratus (Rossmässler, 1835)

Anisus spirorbis (Linnaeus, 1758)

Syn. A. dazuri auct. non [?] (Mörch, 1868)

Anisus vorticulus (Troschel, 1834)

Anisus vortex (Linnaeus, 1758)

Bathyomphalus contortus (Linnaeus, 1758)

Ferrissia fragilis (Tryon, 1863)

Non-native species, occurs in the Dniester Basin (SON 2007, MUNJIU 2012).

Gyraulus acronicus (Férussac, 1807)

It occurs in the Dniester River and Kuchurhan Liman (MUNJIU 2012).

Gyraulus albus (Müller, 1774)

Gyraulus crista (Linnaeus, 1758)

Syn. G. bielzi auct. non [?] (Kimakowicz, 1884)

Gyraulus laevis (Alder, 1838)

Reported from the Dniester Basin (YAROSHENKO 1957, MuNJIU 2012).

Hippeutis complanatus (Linnaeus, 1758)

Syn. Helix fontana (Lightfoot, 1786), Hippeutis diaphanella auct. non [?] (Bourguignat, 1864)

$H$. complanatus occurs in the Kuchurhan Liman and some other water bodies (YAROSHENKO 1957, MunJIU 2012).

Planorbarius corneus (Linnaeus, 1758)

Syn. P. purpura auct. non [?] (Müller, 1774), P. grandis auct. non [?] (Dunker, 1850), P. banaticus auct. non [?] (Lang, 1856)

Planorbis carinatus Müller, 1774

Planorbis planorbis (Linnaeus, 1758)

It occurs in the Dniester and Prut rivers (YAROSHENKO 1957, GONTYA 1984, 1985, MUNJIU 2009, 2012).

Segmentina nitida (Müller, 1774)

Carychiidae Jeffreys, 1830

Carychium minimum Müller, 1774

Carychium tridentatum (Risso, 1826)

Cochlicopidae Pilsbry, 1900

Cochlicopa lubrica (Müller, 1774)

Cochlicopa lubricella (Porro, 1838)

Orculidae Steenberg, 1925

Sphyradium doliolum (Bruguière, 1792)

Valloniidae Morse, 1864

Acanthinula aculeata (Müller, 1774)

Vallonia costata (Müller, 1774)

Vallonia enniensis (Gredler, 1856)

It occurs in the Codry Nature Reserve (BAIDASHNIKOV 1993).

Vallonia excentrica Sterki, 1893

Vallonia pulchella (Müller, 1774)
Pupillidae Turton, 1831

Pupilla muscorum (Linnaeus, 1758)

Vertiginidae Pilsbry, 1918

Columella edentula (Draparnaud, 1805)

It occurs in the Codry Nature Reserve (BAIDASHNIKOV 1993, COADĂ 2000).

Truncatellina claustralis (Gredler, 1856)

It has not been reported in the literature. There are about 20 shells in the material of $\mathrm{A}$. BAIDASHNIKOV from the old oak forest in the Codry Nature Reserve (collection of Schmalhausen Institute of Zoology, Kiev). It was also found by V. COADĂ near Soroca city (northern Moldova, material in private collection).

Truncatellina costulata (Nilsson, 1823)

It occurs in the Codry Nature Reserve (BAIDASHNIKOV, 1993).

Truncatellina cylindrica (Férussac, 1807) It occurs in the Codry Nature Reserve (BAIDASHNIKOV 1993, COADĂ 2000).

Vertigo angustior Jeffreys, 1830

Vertigo antivertigo (Draparnaud, 1801)

Vertigo moulinsiana (Dupuy, 1849)

Vertigo pusilla Müller, 1774

Vertigo pygmaea (Draparnaud, 1801)

Chondrinidae Steenberg, 1925

Granaria frumentum (Draparnaud, 1801)

It has not been reported in the literature, but M. SON found this species near Saharna village in 2005 (material in private collection).

Enidae Woodward, 1903

Brephulopsis cylindrica (Menke, 1828)

Probably a non-native species (GONTYA 1984, SYSOEV \& SCHILEYKO 2009). Numerous population was recently observed by V. COADĂ in Chişinău.

Chondrula tridens (Müller, 1774)

Merdigera obscura (Müller, 1774)

Clausiliidae Mörch, 1864

Balea biplicata (Montagu, 1803)

Bulgarica cana (Held, 1836)

Occurring in the Codry Nature Reserve (BAIDASHNIKOV 1993).

Bulgarica vetusta (Rossmässler, 1836) Reported from northern Moldova (SYSOEV \& SCHILEYKO 2009).

Cochlodina laminata (Montagu, 1803)

Cochlodina orthostoma (Menke, 1830)

Laciniaria plicata (Draparnaud, 1801)

Macrogastra borealis (Boettger, 1878)

Syn. M. latestriata (Schmidt, 1856)

The species occurs in the Codry Nature Reserve (BAIDASHNIKOV 1993). It was also found by V. COADĂ on the Varatic rock in Glodeni district (material in private collection). 
Ruthenica filograna (Rossmässler, 1836)

Serrulina serrulata (Pfeiffer, 1847)

Ferussaciidae Bourguignat, 1883

Cecilioides acicula (Müller, 1774)

Punctidae Morse, 1864

Punctum pygmaeum (Draparnaud, 1801)

Discidae Thiele, 1931

Discus perspectivus (Megerle von Mühlfeld, 1816)

Euconulidae Baker, 1928

Euconulus fulvus (Müller, 1774)

Gastrodontidae Tryon, 1866

Zonitoides nitidus (Müller, 1774)

Zonitidae Mörch, 1864 [sensu RIEDEL 2000 and SHILEYKO 2003, non HAUSDORF 1998]

Aegopinella minor (Stabile, 1864)

Aegopinella pura (Alder, 1830)

Nesovitrea petronella (Pfeiffer, 1853)

It has not been reported in the literature. There is one shell in the material of A. BAIDASHNIKOV from the hornbeam-oak forest in the Codry Nature Reserve (collection of Schmalhausen Institute of $\mathrm{Zo}_{\mathrm{O}}$ ology, Kiev). It was also found by V. COADĂ near Soroca city (northern Moldova, material in private collection).

Oxychilus glaber (Rossmässler, 1835)

Vitrea contracta (Westerlund, 1871)

Vitrea crystallina (Müller, 1774)

Vitrea diaphana (Studer, 1820)

Milacidae Ellis, 1926

Tandonia kusceri (Wagner, 1931)

It was found by V. COADĂ in 2011 in "Valea Farmecilor" city park of Chişinău and in Ciorescu village near Chişinău (material in private collection, anatomically determined). Probably a non-native species.

Vitrinidae Fitzinger, 1833

Vitrina pellucida (Müller, 1774)

Limacidae Refinesque, 1815

Lehmannia jaroslaviae Grossu, 1967

A single finding near "Kipriani" (Capriana) village (SYSOEV \& SCHILEYKO 2009).

Lehmannia marginata (Müller, 1774)

Limax cinereoniger Wolf, 1803

Limax maximus Linnaeus, 1758 Probably a non-native species.

Agriolimacidae Wagner, 1935

Deroceras agreste (Linnaeus, 1758)

Deroceras laeve (Müller, 1774)

Deroceras reticulatum (Müller, 1774)

Deroceras sturanyi (Simroth, 1894)
Deroceras turcicum (Simroth, 1894)

Occurring in the Codry Nature Reserve (BAIDASHNIKOV 1993).

Arionidae Gray, 1840

Arion circumscriptus Johnston, 1828

Arion silvaticus Lohmander, 1937

Arion subfuscus (Draparnaud, 1805) [sensu lato]

Bradybaenidae Pilsbry, 1939

Fruticicola fruticum (Müller, 1774)

Helicidae Rafinesque, 1815

Arianta arbustorum (Linnaeus, 1758)

Cepaea vindobonensis (Férussac, 1821)

Helicigona faustina (Rossmässler, 1835)

It was found near Saharna village in the canyon of Saharna River by M. SON in 2005, material in the collection of the State Natural History Museum in Lvov (GURAL-SVERLOVA \& GURAL 2012).

Helix lutescens Rossmässler, 1837

Helix pomatia Linnaeus, 1758

Hygromiidae Tryon, 1866

Euomphalia strigella (Draparnaud, 1801)

Helicopsis instabilis (Rossmässler, 1838)

Occurring in the Dniester Basin (GONTYA 1984, SYSOEV \& SCHILEYKO 2009).

Helicopsis striata (Müller, 1774)

Lindholmiola girva (Frivaldszky, 1835)

Monacha cartusiana (Müller, 1774)

Perhaps a non-native species (COADĂ \& WELTERSCHULTES 2011).

Monachoides incarnatus (Müller, 1774)

Monachoides vicinus (Rossmässler, 1842)

Perforatella dibotrion (Bielz, 1860)

Pseudotrichia rubiginosa (Rossmässler, 1838)

Occurs in the Codry Nature Reserve (BAIDASHNIKOV 1993, COADĂ 2000).

Trochulus hispidus (Linnaeus, 1758)

Xeropicta derbentina (Krynicki, 1836) Perhaps a non-native species (COADĂ \& WELTERSCHULTES 2011).

Xeropicta krynickii (Krynicki, 1833) Perhaps a non-native species (COADĂ \& WELTERSCHULTES 2011).

Xerolenta obvia (Menke, 1828)

Syn. X. candicans (Pfeiffer, 1841)

Perhaps a non-native species (COADĂ \& WELTERSCHULTES 2011).

Succineidae Beck, 1837

Oxyloma elegans (Risso, 1826)

Oxyloma sarsii (Esmark, 1886)

Occurs in the Codry Nature Reserve (COADĂ 2000).

Succinea putris (Linnaeus, 1758)

Succinella oblonga (Draparnaud, 1801) 


\section{Bivalvia}

Unionidae Fleming, 1828

Anodonta anatina (Linnaeus, 1758)

Syn. A. zellensis (Gmelin, 1791), A. piscinalis

Nilsson, 1823

Anodonta cygnea (Linnaeus, 1758)

Pseudanodonta complanata (Rossmässler, 1835)

Syn. P. rossmaessleri (Bourguignat, 1870)

Sinanodonta woodiana (Lea, 1834)

Non-native species, occurs in the Prut Basin (MUNJIU 2009, MUNJIU \& SHUBERNETSKI 2010).

Unio crassus Philipsson, 1788

Unio pictorum (Linnaeus, 1758)

Syn. U. longirostris (Rossmässler, 1836)

Unio tumidus Philipsson, 1788

Occurs in the Dniester and Prut rivers (YAROSHENKO 1957, MUNJIU 2009, 2012).

Sphaeriidae Deshayes, 1855

Musculium lacustre (Müller, 1774)

Pisidium amnicum (Müller, 1774)

Pisidium casertanum (Poli, 1791)

Pisidium henslowanum (Sheppard, 1823)

Reported from the Dniester River (YAROSHENKO 1957, MuNJIU 2009, 2012).

Pisidium milium Held, 1836

Syn. P. tetragonum Normand, 1854

Reported from the Dniester River (MUNJIU 2009, MUNJIU 2012).

Pisidium nitidum Jenyns, 1832

Reported from the Dniester River (YAROSHENKO 1957, Munjiu 2012).

Pisidium pulchellum Jenyns, 1832

Reported from the Dniester River (YAROSHENKO 1957, Munjiu 2012).

Pisidium subtruncatum Malm, 1855

Reported from the Dniester Basin (YAROSHENKO 1957, MuNJIU 2012).

Pisidium supinum Schmidt, 1851

Sphaerium corneum (Linnaeus, 1758)

\section{DISCUSSION}

Besides the listed species several names of marine and brackish water forms such as Turricaspia variabilis (Eichwald, 1838), T. pseudotriton (Golikov et Starobogatov, 1966), T. limanica (Golikov et Starobogatov, 1966), Caspia gmelinii Clessin et Dybowski, 1888, C. knipowitchi Makarov, 1938, C. makarovi (Golikov et Starobogatov, 1966), Caspiohydrobia eichwaldiana (Golikov et Starobogatov, 1966), Ecrobia ventrosa (Montagu, 1803), Hydrobia acuta (Draparnaud, 1805) and Cerastoderma lamarcki (Reeve, 1845) were reported from the Republic of Moldova (GONTYA 1985, MUNJIU 2012). However
Sphaerium rivicola (Lamarck, 1818)

Sphaerium solidum (Normand, 1844)

Reported from the Dniester River (YAROSHENKO, 1957; MunjIU, 2012).

Dreissenidae Gray, 1840

Dreissena polymorpha (Pallas, 1771)

Dreissena rostriformis (Deshayes, 1838)

Represented by its pontic subspecies $-D$. rostriformis bugensis Andrusov, 1897. Non-native species, occurs in Dniester and Prut rivers (MUNJIU 2009, 2012, MUNJIU \& SHUBERNETSKI 2010).

Corbiculidae Gray, 1847

Corbicula fluminea (Müller, 1774)

Non-native species, first record in 2009, Prut River (MunJiU \& SHUbernetsKi 2010, MunjIU 2012).

Cardiidae Lamarck, 1809

Hypanis colorata (Eichwald, 1829)

Reported from the Kuchurhan Liman (VLADIMIROV 1984, GONTYA 1985, MUNJIU 2012). Listed in the Red Book of Moldova (official national Red List).

Hypanis laeviuscula (Martens, 1874)

Reported from the Dniester River and Kuchurhan Liman (YAROSHENKO 1957, VlaDIMIROV 1984, GONTYA 1985, MUNJIU 2012). Represented by its pontic subspecies - H. laeviuscula fragilis (Milaschewitsch, 1908). Listed in the Red Book of Moldova.

Hypanis plicata (Eichwald, 1829)

Reported from the Kuchurhan Liman (GONTYA 1985, MunjIU 2012). Represented by its pontic subspecies - H. plicata relicta (Milachevitch, 1916).

Hypanis pontica (Eichwald, 1838)

Reported from the Dniester River and Kuchurhan Liman (YAROSHENKO 1957, VLADIMIROV 1984, GONTYA 1985, MUNJIU 2012). Listed in the Red Book of Moldova. these reports may refer to the Dniester Liman in Ukraine or could be based on fossil shells or shells that were occasionally transferred to Moldova by birds or man. Moreover the taxonomic status of some of these forms is unclear and we did not verify their determinations. Marine ecosystems are absent in Moldova. The only brackish water body in Moldova is the Kuchurhan Liman. The Moldavian border is adjacent to the Dniester Liman in Ukraine, but it does not touch it. Some brackish water species invaded the Dniester River in Moldova. In 1964 the Kuchurhan Liman was turned into a cooling reservoir of a 
Moldavian power station, so it is regulated and polluted. Currently Ponto-Caspian molluscs of Hydrobiidae and Cardiidae are receding and rare in Kuchurhan, some species are probably extinct, others are threatened in Moldova.

Reports of Ena montana (Draparnaud, 1801) and Helix albescens Rossmässler, 1839 (as H. vulgaris Rossmässler, 1839) from the Codry Nature Reserve (GONTYA 1984) and of Daudebardia cavicola Soós, 1927 from the Dniester valley (VITION 2004) should be confirmed. Reports of Vertigo substriata (Jeffreys, 1833) and Perforatella bidentata (Gmelin, 1791) from the Codry Nature Reserve (COADĂ 2000) are not confirmed here.

Some species like Pisidium globulare Westerlund, 1873, P. hibernicum Westerlund, 1894, P. moitessierianum Paladilhe, 1866, P. obtusale (Lamarck, 1818), P. personatum Malm, 1855, Sphaerium ovale (Férussac, 1807), S. nucleus (Studer, 1820), Viviparus acerosus Bourguignat, 1862, Cochlicopa nitens (Gallenstein, 1848), Pupilla bigranata (Rossmässler, 1839), Chondrina arcadica (Reinhardt, 1881), Discus ruderatus (Férussac, 1821), Nesovitrea hammonis (Strøm, 1765), Malacolimax tenellus (Müller, 1774), Deroceras moldavicum (Grossu et Lupu, 1961) and Arion fasciatus (Nilsson, 1823) were only suggested to live in the Republic of Moldova (WELTER- SCHULTES 2012), but there are no known findings so far. At least $D$. ruderatus and $N$. hammonis are very likely to be found in Moldova, since these species are quite common in adjacent regions of Romania and Ukraine (GROSSU 1983, BALASHOV \& GURAL-SVERLOVA 2012).

Several more mollusc species were listed for the Republic of Moldova in some respectable official websites. However no references were established. It is possible that these reports were based on the confusion with Moldova, a historical region in adjacent Romania (today officially called the "Principality of Moldavia"). "Moldova" was used in the titles of several papers about molluscs of Romania only.

From our observations at least some terrestrial species such as Pomatias rivularis, Platyla polita, Vertigo moulinsiana, Truncatellina claustralis, Granaria frumentum, Serrulina serrulata, Ruthenica filograna, Macrogastra borealis and Discus perspectivus are threatened in the Republic of Moldova and should be included in the official national Red List, the Red Book of Moldova. The problems of mollusc conservation in Moldova should be studied separately and in detail, this has not been done yet.

\section{ACKNOWLEDGEMENTS}

We are grateful to Dr. OxANA V. MUNJIU (Institute of Zoology, Academy of Sciences of Moldova) for her comments regarding a previous manuscript of this paper.

\section{REFERENCES}

ANISTRATENKO O. YU., STAROBOGATOV YA. I., ANISTRATENKO V. V. 1999. Mollyuski roda Theodoxus (Gastropoda, Pectinibranchia, Neritidae) Azovo-Chernomorskogo basseyna. Vestnik Zoologii 3(33): 11-19.

BAIDASHNIKOV A. A. 1993. Nazemnye mollyuski (Gastropoda, Pulmonata) zapovednika Kodry (Moldova). Vestnik Zoologii 4: 10-15.

BALASHOV I., GURAL-SVERlOVA N. 2012. An annotated checklist of the terrestrial molluscs of Ukraine. J. Conch. 41: 91-109.

Bunje P. M. E. 2005. Pan-European phylogeography of the aquatic snail Theodoxus fluviatilis (Gastropoda: Neritidae). Mol. Ecol. 14: 4323-4340. http://dx.doi. org/10.1111/j.1365-294X.2005.02703.x

BUNJE P. M. E. 2007. Fluvial range expansion, allopatry, and parallel evolution in a Danubian snail lineage. Biol. J. Linn. Soc. 90: 603-617. http://dx.doi.org/10.1111/ j.1095-8312.2007.00750.x

COADĂ V. 2000. Malakofauna lesnogo zapovednika "Kodry" Respubliki Moldova. Fourth (Thirteenth) Conference on the Study of Molluscs: Molluscs: taxonomy, ecology and phylogeny. St. Petersburg, Russia, 27-29 October, 1998. Abstracts, Zoological Institute RAS, St. Petersburg: 19-20.
COADĂ V., WELTER-SCHULTES F. 2011. Checklist of land and freshwater mollusc species in Moldova. Schrift. Malakozool. 26: 41-46.

Gîlcă G., ŞTirbu S., Luchianova V., Gudzi T., ȚURCANU V., IALOVIŢCAIA N., RUSU E. 2010. Starea ecologică a apei fluviului nistru în baza elementelor hidrobiologice pentru anul de referință 2009. Proceedings of the International Scientific and Practical Conference: Dniester river basin: environmental issues and management transboundary natural resources. 15-16 October 2010. NGO «Ecospectr», Tiraspol: 60-63.

GONTYA F. A. 1984. Klass Bryuhonogiye. In: Mshanki, mollyuski, chlenistonogiye. Seriya Zhivotnyj mir Moldovy. Animal World of Moldova, Shtinica, Kishinev, pp. 13-30.

GONTYA F. A. 1985. Malakofauna vodoemov basseyna Dnestra. Abstract of a thesis for the scientific degree of candidate of biological sciences, Chisinau.

Grossu A. V. 1983. Gastropoda Romaniae 4. Ordo Stylommatophora. Suprafam.: Arionacea, Zonitacea, Ariophantacea şi Helicacea. Editura Litera, Bucureşti.

GURAL-SVERLOVA N. V., GURAL R. I. 2012. Naukovy kolekcyi Derzhavnogo pryrodoznavchogo muzeyu. Vyp. 4. Malakologłchnyj fond. Derzhavnyj pryrodoznachij muzey, Lvov. 
HAUSDORF B. 1998. Phylogeny of the Limacoidea sensu lato (Gastropoda, Stylommatophora). J. Mollus. Stud. 64: 35-66. http://dx.doi.org/10.1093/mollus/64.1.35

MunJIU O. 2009. The biodiversity of freshwater mollusc in Moldova in the places with different degree of anthropogenic activity. Proceedings of the International Conference: Transboundary River Basin Management and International Cooperation for Healthy Dniester River. Odessa, September 30-October 1, 2009: 193-197.

MunjIU O. 2012. Sovremennyi vidovoy sostav presnovodnykh mollyuskov Moldovy. Proceeding of the international conference: Geoecological and bioecological problems of the north Black Sea coast.. Tiraspol, November 9-10, 2012: 205-207.

Munjiu O., SHubernetski I. 2010. First record of Asian clam Corbicula fluminea (Müller, 1774) in the Republic of Moldova. Aquatic Invasions 5(suppl. 1): 67-70. http://dx.doi.org/10.3391/ai.2010.5.S1.015

Riedel A. 2000. Die Sammlung der Paläarktischen Zonitidae sensu lato (Gastropoda, Stylommatophora) in dem Museum und Institut für Zoologie der PAdW in Warszawa. Folia Malacol. 8: 37-85.

Sereda S. V., Albrecht C., Anistratenko V. V., Wilke T. 2007. Diversification of the genus Theodoxus (Neritidae) in the Black Sea Basin. Abstracts of World Congress of Malacology, Antwerp, Belgium, 15-20 July 2007: 203-204.

SCHILEYKo A. A. 2003. Treatise on recent terrestrial pulmonate molluscs. Part 10: Ariophantidae, Ostracolethidae, Ryssotidae, Milacidae, Dyakiidae, Staffordiidea, Gastrodontidae, Zonitidae, Daudebardiidae, Parmacellidae. Ruthenica (Suppl. 2) 10: 1309-1466.

Son M. O. 2007. North American freshwater limpet Ferrissia fragilis (Tryon, 1863) - the cryptic invader in the Northern Black Sea Region. Aquatic Invasions 2: 55-58. http://dx.doi.org/10.3391/ai.2007.2.1.6
SON M. O. 2008. Rapid expansion of the New Zealand mud snail Potamopyrgus antipodarum (Gray, 1843) in the Azov-Black Sea Region. Aquatic Invasions 3: 335-340. http://dx.doi.org/10.3391/ai.2008.3.3.9

SON M. O. 2010. Alien mollusks within the territory of Ukraine: sources and directions of invasions. Russian J. Biol. Invasions 2: 37-48. http://dx.doi.org/10.1134/ S207511171001008X

Starobogatov Ya. I., Prozorova L. A., Bogatov V. V., SAYENKO E. M. 2004. Mollyuski. In: Opredilitel presnovodnykh bespozvonochnykh Rossii i sopredelnikh territoriy. T. 6. Mollyuski, Polikhety, Nemertiny. Nauka, Saint Petersburg, pp. 9-492.

Sysoev A., Schileyko A. 2009. Land snails and slugs of Russia and adjacent countries. Pensoft, Sofia.

ViTION P. 2004. Studiul zoocomplexuluiedafic din lunca riului Nistru. Proceedings of the International Conference: Integrated management of natural resources in the transboundary Dniester River Basin. Chisinau, September 16-17, Eco-TIRAS: 77-79.

VLADIMIROV M. Z. 1984. Klass Dvustvorchatye. In: Mshanki, mollyuski, chlenistonogiye. Serija Zhivotnyj mir Moldovy. Animal World of Moldova series, Shtinica, Kishinev. pp. $31-45$.

YARoshenko M. F. 1957. Gidrofauna Dnestra. Izdatelstvo Akademii Nauk SSSR, Moscow.

WelteR-SChUltes F. W. 2012. European non-marine molluscs, a guide for species identification. Planet Poster Editions, Göttingen.

Received: May 25th, 2013

Revised: June 23rd, 2013

Accepted: June 25th, 2013 